\title{
Ecodesign of organic photovoltaic modules from Danish and Chinese perspectives
}

\author{
Espinosa Martinez, Nieves; Laurent, Alexis; Krebs, Frederik C
}

Published in:

Energy \& Environmental Science

Link to article, DOI:

$10.1039 / \mathrm{c} 5 \mathrm{ee} 01763 \mathrm{~g}$

Publication date:

2015

Document Version

Peer reviewed version

Link back to DTU Orbit

Citation (APA):

Espinosa Martinez, N., Laurent, A., \& Krebs, F. C. (2015). Ecodesign of organic photovoltaic modules from Danish and Chinese perspectives. Energy \& Environmental Science, 8, 2537-2550.

https://doi.org/10.1039/c5ee01763g

\section{General rights}

Copyright and moral rights for the publications made accessible in the public portal are retained by the authors and/or other copyright owners and it is a condition of accessing publications that users recognise and abide by the legal requirements associated with these rights.

- Users may download and print one copy of any publication from the public portal for the purpose of private study or research.

- You may not further distribute the material or use it for any profit-making activity or commercial gain

- You may freely distribute the URL identifying the publication in the public portal

If you believe that this document breaches copyright please contact us providing details, and we will remove access to the work immediately and investigate your claim. 


\title{
Ecodesign of organic photovoltaic modules from Danish and Chinese perspectives
}

\author{
Nieves Espinosa ${ }^{1}$, Alexis Laurent ${ }^{2}$ and Frederik Krebs ${ }^{1, *}$ \\ ${ }^{1}$ Department of Energy Conversion and Storage, Technical University of Denmark, Frederiksborgvej 399, \\ DK-4000 Roskilde, Denmark. \\ ${ }^{2}$ Division for Quantitative Sustainability Assessment, Department of Management Engineering, Technical \\ University of Denmark (DTU), Produktionstorvet 424, DK-2800 Kgs. Lyngby, Denmark.
}

* To whom correspondence should be addressed; e-mail: frkr@dtu.dk , Tel.: (+45) 46774799

Keywords: OPV solar cells; life cycle assessment (LCA); life cycle inventory; Denmark; China

\begin{abstract}
The life cycle of a solar park made with organic photovoltaic (OPV) technology is assessed here. The modules have been fabricated in a pilot scale plant and they have been installed together with other components to evaluate the balance of system, in a solar park located in Denmark. Three possible waste management practices have been contemplated for the end of life of the solar park: recycling, incineration or the average local mix. The assessment of the environmental impacts of such a system reveals that silver used in the electrodes is overall the largest source of impacts, such as chemical pollution and metal depletion. The establishment of resource recovery systems for the end-of-life management of the OPV modules is then crucial to reduce overall environmental impacts. Liability on the manufacturers or on the operators should be implemented. The electricity produced from OPV solar parks yields similar footprint to other traditional energy technologies; e.g. coal and natural gas. However, when the efficiency of the OPV modules is increased from $1 \%$ to to $5 \%$ they are comparable to other mature PV technologies already on the market. The effects of outsourcing or exporting the production of the OPV modules from Denmark to China have additionally been studied to determine the most advantageous choice. The stakeholders should aim at anchoring the manufacturing of solar parks in countries with stringent emission standards or high technology efficiencies, and at deploying them in countries with high irradiation to maximise the environmental benefits of the PV technology.
\end{abstract}

\section{Introduction}

Organic Photovoltaics (OPV) in the form that could represent future technology at the time was reported in 1995 and since then it has gradually developed and today it is an emerging energy technology. From the first devices that were fabricated on the scale of square millimetres, intense research efforts during the past decade have brought OPV closer to contend with well stablished photovoltaic (PV) technologies. They possess unique properties; low weight, the potential to be manufactured cheaply and everywhere without special equipment, and with low energy budget. In terms of the environmental aspects they already surpass other energy technologies and they hold the potential of progressing much beyond inorganic based PV modules. There are however open questions and limitations of the technology rooted in their relatively poor area efficiency and shorter lifetime when compared to traditional PV cells. This can be viewed as drawbacks but can be an advantage in the case where a technology is rapidly improving and the replacement of expired solar cells can be carried out with limited effort with better efficiency cells. 

perspectives. Energy and Environmental Science 8, 2537-2550. DOI: 10.1039/C5EE01763G.

The fast growth of global energy consumption is one of the largest challenges facing mankind today that can only be addressed with the introduction of new sustainable and renewable energy technologies. These systems should be designed with a completely new approach taking into account that everything comes from nature and everything matters. How we extract material, how we convert and use the material, how we dispose of it all influence the overall environmental impact. Designing new technology with a view all the way to the stage of disassembly, looking for light-weighting and for eco-materials, can lead to reduce the net environmental impacts and make the so called circular economy for the energy field come true. In this way we anticipate the impacts before they occur in the early stages of development of a new technology such as the polymer solar cells.

Environmental life cycle assessment (LCA) is a scientific approach behind modern environmental policies and business decision support related to sustainable production and consumption. It should be carried out in four phases, according to ISO norms 14040 and 14044, which are normally interdependent and iterative: goal and scope definition, life cycle inventory analysis, life cycle impact assessment and interpretation. After defining the goal of the study and the system scope (step 1), and based on a collected Life cycle inventory (step 2), where all emissions released into the environment and resources extracted from nature along the whole life cycle of a product are listed in a table or life cycle inventory (LCI). The subsequent Life Cycle Impact Assessment (LCIA) (step 3) classifies the inventoried substances according to their contribution to environmental impact categories (e.g., Global Warming Potential) and characterizes them by their significance in relation to the reference unit (e.g., $\mathrm{kg} \mathrm{CO}_{2}$-equivalent). The Interpretation of the results (step 4) is carried out depending on the main questions that should be answered within the study; the results can be used for strategic planning of product improvements (as support for environmental management systems), for benchmarking or for the compliance to environmental directives.

Until now previous reports where the LCA tool has been applied to OPV have been published with different purposes. ${ }^{1-10}$ The most ambitious and true to the art of using LCA and LCIA is to achieve improvements where real manufacturing data are used as input and the output from the analyses being used to improve and progress processing routes for a given technology. This iterative approach enables steep improvements in technology and its potential impacts. The least ambitious approach has been to review already published LCA studies with minor re-interpretations or use of published data as a basis for an out-of-context analysis. ${ }^{11}$ While this can be justified for preliminary estimations when real data is lacking it is highly inaccurate. Most of the uncertainties in LCAs are greatly reduced when goals and boundaries are consistent, when an explicit methodology is used, ${ }^{14}$ and when real data (and not cherry picked laboratory data) are used. The majority of reports reviewed here are limited to examining greenhouse gas emissions and/or energy. ${ }^{3,5-7}$ Preliminary investigations of the environmental profile of OPV at the manufacturing stage have identified the electrical power consumption of the production processes to cause the main contributions to primary energy demand and climate change potential. ${ }^{3,12,8}$ Another aspect is that little attention has been paid into LCA studies (also for other PV technologies) to other components of a PV installation or the so called balance of system (BOS) ${ }^{13}$ Therefore, inventory data for BOS components are scarce. Due to the narrow scope of the majority of the previous reports we will with this report progress to a "whole life cycle perspective", addressing a large range of impact categories during all life stages of a solar park including the disposal stage - which is frequently forgotten or omitted. Therefore, to realize this task we have built a life cycle inventory (LCI) of the complete solar park using real data. To raise ambition further we encompass eco-design with environmental impact reduction (optimisation) for the first time in the OPV technology addressing the following issues: 

perspectives. Energy and Environmental Science 8, 2537-2550. DOI: 10.1039/C5EE01763G.

1. Releasing LCI data for a solar park in Denmark at the current technology level. Actual process data were collected and we aim to provide full disclosure of the data and associated life cycle inventories pertaining to the modelling of a Danish solar park.

2. Identifying environmental hotspots, i.e. where the largest environmental impacts are located in the system. Recommendations on their reductions are provided.

3. Addressing the uncertainties concerning the disposal of the system has been achieved by the inclusion of different scenarios for the end of life scenarios for a solar park based on organic solar modules.

4. Investigating the influence of location of the solar park between diverse countries such as China and Denmark, and also investigating the environmental benefits/impacts of outsourcing or exporting the solar park from a Danish perspective.

\section{Methods}

\subsection{Overview of the solar park}

The study focuses on a solar park installed at the Technical University of Denmark (DTU) in Roskilde, Denmark. It is a ground-mounted system installed in spring 2013 with a capacity of up to $6 \mathrm{~kW}_{\mathrm{p}}$ of OPV modules - with the scaled efficiency at the time ${ }^{15}$. The process to manufacture the OPV modules takes place at the same location as the solar park; it has been previously described and analysed. ${ }^{12,16,17}$ OPV modules are typically composed of 6 layers that can be deposited by coating or printing techniques, generally following a drying process in an oven. Two electrodes, three intermediate layers and the active layer are printed on long rolls in a continuous process, and all individual cells are connected endlessly in series, thus giving the process and the technology the name "infinity". ${ }^{15}$ Final packaging of the solar cells is achieved using the same roll-to-roll methodologies. Consumptions of materials, electricity and heat for the manufacture of the modules have therefore been measured accurately from the real processes on the real printing machinery in operation at DTU. This includes the installation, operation and decommissioning of the solar cell foil.

Any solar cell technology needs a group of additional components in order to be deployed as a solar park: this is known as balance of system (BOS). OPV modules do not need a frame but only require to be attached when they are rolled out onto a structure, e.g. wooden structure (as considered herein). The modules are mounted on a wood structure, and to insulate the wood from the solar cells, it is necessary to place an insulator that has fire retardant properties and provides rear ventilation to the plastic substrate. The currently used insulator is a PET grid, although a number of other plastics could act as insulators. The power is converted from direct current (DC) to alternating current (AC) in the inverter and the necessary connections include wiring, fuses and electric monitoring systems. Major components are visible in Fig. 1 and have been modelled to represent the already operating solar park. Detailed descriptions can be found in Tables SM5 and SM7 in the supporting information (ESI-Methods $\dagger$ ). The area related parameters have been adapted based on actual average module efficiencies. 
18
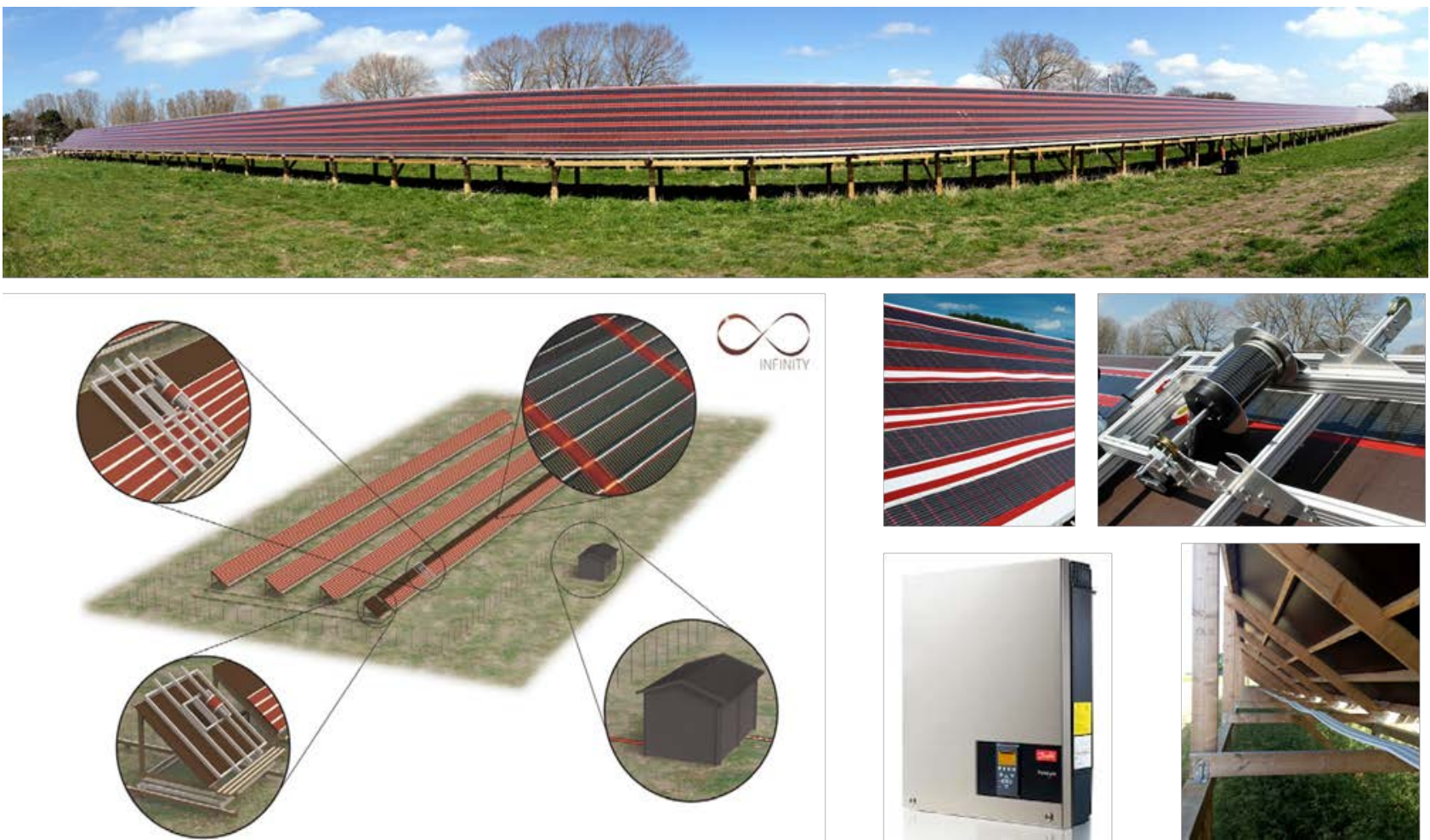

Fig. 1. Solar park at DTU in Denmark, with OPV modules based in Infinity concept (reprinted with permission from Wiley ${ }^{15}$ ).

\subsection{Boundaries and scope of the study}

The International Reference Life Cycle Data System (ILCD) Handbook, which provides detailed technical guidance on how to conduct LCA studies, was followed to perform the current study. ${ }^{18}$ The entire life cycle of the solar park system is encompassed, i.e. from the supply of the raw materials used in the production, along the manufacturing and assembly of the parts and the subsequent operations of the solar park, to its final end-of-life. An overview of the system is shown in Fig. 2 - see also detailed view in the supporting information (Fig. SM1 in ESI-Methods $\dagger$ ).

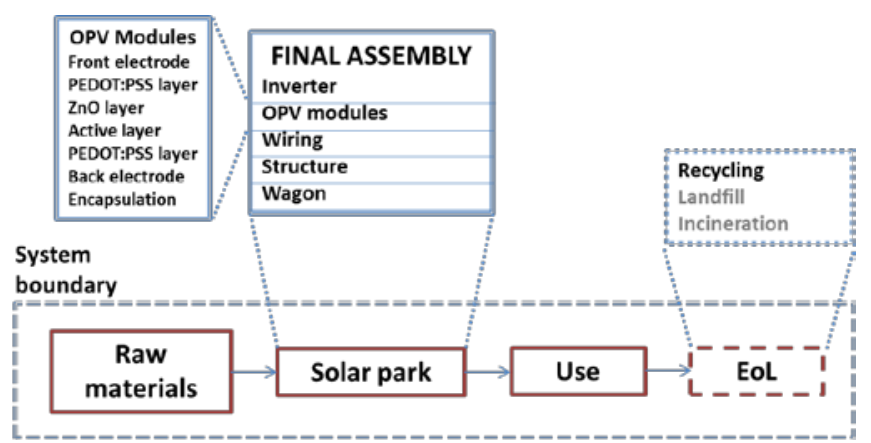

Fig. 2. Life cycle of the solar park including the analysed system boundaries. Materials and energy recoveries from the end-of-life stage are included in the system boundaries. Details on the system boundaries are provided in ESI-Methods $†$ and Section 2.3.

The functional unit (FU), which quantifies the primary function of the solar park and allows for comparative assessments, is defined as the supply of on average one kWh of electricity (at high voltage) produced from 

perspectives. Energy and Environmental Science 8, 2537-2550. DOI: 10.1039/C5EE01763G.

the OPV solar park to the grid in Denmark (for the scenarios related to installation in Denmark) or in China (for the scenarios where the solar park is deployed in China). This supply of electricity requires $0,016 \mathrm{~m}^{2}$ and $0,010 \mathrm{~m}^{2}$ in Denmark and China, respectively. Default total area module efficiency of $1 \%$ and a total system performance ratio of $80 \%$ for ground-mounted installations are considered (see also Section 2.5 for sensitivity scenarios). ${ }^{19}$

According to the ILCD Handbook, the current assessment can be identified as a situation A- or B-type depending on the extent of the consequences from the deployment of the solar park on the market. Given the primary goals of the study, an A-type situation context is more likely (eco-design study). An attributional modelling framework is therefore considered with use of system expansion to model the interactions with other external systems. ${ }^{18}$ This allows for crediting the system when materials and energy are recovered, e.g. in recycling or incineration processes, and thus substitute their generation from conventional production pathways. $^{20}$ The ecoinvent 3.1 database (consequential) ${ }^{21,22}$, which was used as backbone for life cycle inventory data (see Section 2.3), allows such modelling framework but the crediting is designed to account for the processes, which are most likely to respond to a change in demand (marginal processes), and not the average market situation, as required by the ILCD Handbook. ${ }^{18,22}$ These discrepancies are however not deemed to influence the results of the study with regard to the goals.

The analysed scenarios (see Section 2.5) address manufacturing and deployment of the solar park in Denmark and/or China. The primary data used for modelling were differentiated between the two countries with regard to the solar park performances, e.g. OPV module outputs adapted to different solar irradiation profiles for China (Section 2.3.2), and with respect to generic processes, e.g. electricity mixes and generation technologies adapted to actual situations in each of the two countries (see also Section 2.3). Details about this spatial differentiation of the processes and the associated data used in the modelling are highlighted in Section 2.3 and are fully described in the supporting section (ESI-Methods $\dagger$ ).

\subsection{Life cycle inventory}

Primary data were collected from the manufacturing site at DTU (see Section 2.3.1). Background data, such as energy production processes or waste management processes, were collected from the consequential ecoinvent database v. 3.1, 2014 which is one of the most comprehensive databases for life cycle inventories. Adaptations of life cycle inventories were however required for several processes to ensure representativeness of the modelled scenarios.

The model was built in LCA software SimaPro v. 8.04.26. ${ }^{23}$ The building of the system model, including the data collection, data treatments and assumptions, are fully documented in the supporting section (ESIMethods) $\dagger$ while the key aspects within each life cycle stage are addressed in the subsequent sections. The LCI is provided in electronic format, Table S15, ESI-2†.

\subsubsection{Manufacturing stage of the solar park}

Data were obtained from an experimental solar park in Denmark (DTU), with the OPV modules fabricated on a pilot-scale, thus leading to highly representative data. Background life cycle inventories from the ecoinvent database were combined with the known materials and energy requirements for the manufacture of the OPV modules. The ecoinvent 3.1 database, which includes spatial differentiation of the processes (e.g. energy mixes, technology efficiency differences, etc.), mirrors market mechanisms allowing for modelling supply of materials and energy in a representative way. ${ }^{24}$ Production volumes for 2008 were used to design the market fluxes, ${ }^{24}$ with the exception of the electricity and heat supply mixes for Denmark, which were 

perspectives. Energy and Environmental Science 8, 2537-2550. DOI: 10.1039/C5EE01763G.

built to represent 2013 (latest year of available data). ${ }^{25}$ Production of the solar cells in Denmark and China is therefore modelled with processes representative of these two countries (e.g. energy processes). Transportation distances were also adjusted accordingly. In the current study, the BOS additionally includes insulating sheets, inverters, mounting structures, wiring and connectors. Large-scale ground-mounted PV installations would require additional equipment and facilities, such as grid connections, offices and concrete; those were excluded from the assessment because of their expected negligible impact on the results. Table 1 summarises the BOS and its overall modelling in the study.

Table 1. Modelling of the modules and balance of system (BOS) for the OPV solar park. ${ }^{\mathrm{a}}$ The data source relative to BOS is site specific measurements. ${ }^{\mathrm{b}}$

\begin{tabular}{|c|c|}
\hline $\begin{array}{l}\text { BOS } \\
\text { components }\end{array}$ & Life cycle inventory treatment \\
\hline Solar cells & $\begin{array}{l}\text { Background raw materials production } \\
\text { from ecoinvent } 3.1 \text { database }\end{array}$ \\
\hline Structure & $\begin{array}{l}\text { Background raw materials production } \\
\text { from ecoinvent } 3.1 \text { database }\end{array}$ \\
\hline Inverter & $\begin{array}{l}\text { Adjusted to LCI for inverters available } \\
\text { in ecoinvent } 3.1\end{array}$ \\
\hline Wiring & $\begin{array}{l}\text { Adjusted to LCI for cabling available } \\
\text { in ecoinvent } 3.1\end{array}$ \\
\hline $\begin{array}{l}\text { Aluminium } \\
\text { Wagon }\end{array}$ & $\begin{array}{l}\text { Adjusted to LCI for aluminium frame } \\
\text { production available in ecoinvent } 3.1\end{array}$ \\
\hline $\begin{array}{l}\text { Insulating } \\
\text { sheet }\end{array}$ & $\begin{array}{l}\text { Polyethylene terephthalate (default } \\
\text { scenario) production available in } \\
\text { ecoinvent } 3.1\end{array}$ \\
\hline
\end{tabular}

\subsubsection{Use stage}

During the operation of the solar park (i.e. use stage), the system generates electricity. According to the goal and scope definitions (Section 2.2), the system is therefore passive. No maintenance is considered (in line with actual pilot plant operations) and a commonly employed performance ratio of $80 \%$ for utility groundmounted PV installations has been assumed to account for the losses during operation. ${ }^{19}$

The generation of electricity per unit of OPV area over the lifetime of the modules (default value of 1.5 years) was calculated based on the irradiation levels in both Denmark and China, i.e. 1100 and 1700 $\mathrm{kWh} / \mathrm{m}^{2}$.yr, respectively, ${ }^{26,27}$ and with the considered module efficiency (i.e. $1 \%$ taken as default value). Variations in the lifetime and efficiency of the OPV modules in Denmark were included in the sensitivity analysis to assess their influences on the overall environmental impacts (Section 2.5). The lifetime of the other components were also considered to scale with the required functional unit -see ESI-Methods for further details. $\dagger$

\subsubsection{Disposal stage}

The disposal of the OPV solar park is however difficult to foresee as only few of the historically deployed PV installations have reached this stage and no reports about their disposal are to our knowledge publicly available. To encompass these uncertainties, different scenarios were outlined and included in the assessment for modelling the disposal of the OPV modules in both Denmark (3 scenarios) and China (6 scenarios). Table 2 describes these nine scenarios and their respective modelling assumptions (see ESI-Methods $\dagger$ for 

perspectives. Energy and Environmental Science 8, 2537-2550. DOI: 10.1039/C5EE01763G.

full documentation). The OPV modules contain valuable materials that can easily be recovered, in particular the silver, which can be regarded as a scarce resource, and the PET from the encapsulation, which has a high degree of purity. The remaining parts are primarily composed of mixed plastics, which are considered to be burned due to the difficulty of separating them. Electricity and heat can thus be recovered if the incinerator is coupled with a combined heat and power (CHP) plant, as is the case in Denmark (also assumed for China). This recycling configuration for the OPV modules fits situations, where the responsibility of the disposal falls onto the producer or the operator of the solar park; the OPV modules could then be handled as industrial or hazardous waste by a specialised company. This recycling scenario (i.e. DK-1) is therefore considered the most likely scenario, and is taken as the default scenario in the assessment (see Section 2.5). The results of the comparative analysis of scenarios will therefore determine, given the hazardous nature of some materials, the environmental impacts when the OPV modules are not recycled (i.e. DK-2, DK-3).

The recycling procedure for the OPV modules includes 3 major steps: (i) delamination to recover the PET encapsulation, (ii) acid treatment to recover silver, (iii) incineration of the remaining parts with energy recovery (see full documentation in ESI-Methods $\dagger$ ). When entering the market, the recovered materials and energy substitute production efforts that would have occurred otherwise, hence their modelling includes the saved impacts from the non-utilisation of virgin materials and conventional energy production. $100 \%$ of the PET encapsulation is assumed to be recuperated from the delamination process. The wet process used to recuperate silver is modelled with a recovery yield of $95 \% .{ }^{9}$ Plastics, e.g. PET, and silver are assumed to be recovered after separation in Denmark with rates of $88 \%$ and $76 \%$, respectively. ${ }^{28}$ Because of the large PET content in the OPV modules, i.e. ca. $85 \mathrm{wt} \%$, the incineration of the remaining parts are modelled as incineration of PET, with adaptations of the electricity and heat recovered to match country-specific efficiencies. $^{28}$

Other components than the OPV modules in the solar park were modelled with the assumption of one single disposal route. The inclusion of single disposal routes for these components of the solar park is motivated by the negligible or minor contribution of these parts to the overall environmental burden of the system (see results in Section 3.1). The most likely disposal routes were selected for each component. Inverters, batteries and cabling thus undergo waste management processes as waste electrical and electronic equipment (WEEE); these treatments are already embedded in their life cycle inventories in the ecoinvent 3.1 database. The aluminium wagon is assumed to be entirely recycled. The insulator and wood structure are also assumed to be recycled by default. However this last assumption is tested through one scenario in which both materials are considered to be incinerated (see Section 2.5).

Table 2. Disposal scenarios considered in Denmark and China. ${ }^{a}$

\begin{tabular}{|c|c|c|c|c|}
\hline Name & Description and modelling assumptions & $\begin{array}{c}\text { REC }^{\mathrm{a}} \\
(\%)\end{array}$ & $\begin{array}{c}\text { INC }^{\mathrm{a}} \\
(\%)\end{array}$ & $\begin{array}{c}\mathrm{L}^{\prime} \mathrm{OD}^{\mathrm{a}} \\
(\%)\end{array}$ \\
\hline DK-1 & $\begin{array}{l}\text { OPV modules are assumed to have their valuable materials extracted (PET and } \\
\text { silver) before the remaining parts are sent to incineration for energy recovery } \\
\text { (electricity and heat). Situations where the responsibility of the disposal falls } \\
\text { onto the manufacturer or the operator is thus assumed. The detailed recycling } \\
\text { procedure is outlined in Section 2.3.3. For incineration, LCI for PET } \\
\text { incineration was used with updated incinerator efficiencies. }\end{array}$ & 100 & 0 & 0 \\
\hline DK-2 & $\begin{array}{l}\text { OPV modules are assumed to be collected and directly sent to incineration with } \\
\text { energy recovery (electricity and heat). Because of the large PET content in the } \\
\text { OPV modules ( } 85 \mathrm{wt} \% \text { ), LCI for incineration of PET was used with } \\
\text { adjustments of silver emissions and updated incinerator efficiencies. }\end{array}$ & 0 & 100 & 0 \\
\hline
\end{tabular}




\begin{tabular}{|c|c|c|c|c|}
\hline DK-3 & $\begin{array}{l}\text { An average mix representative of municipal solid waste (MSW) is considered } \\
\text { and assumed to represent a large and diffuse deployment of OPV in Denmark. } \\
\text { Recycling and incineration are modelled as in DK1 and DK-2, respectively. } \\
\text { Landfilling of PET is assumed for the landfilling of OPV modules, with } \\
\text { adjustments for Ag emissions. }\end{array}$ & 29 & 69 & 2 \\
\hline $\mathrm{CN}-1$ & $\begin{array}{l}\text { OPV modules are assumed to be recycled via existing informal recycling sector } \\
\text { and willingness of the manufacturer or operator to recover valuable materials } \\
\text { and energy. Same procedure as for DK-1 is assumed with adaptations to } \\
\text { Chinese conditions, wherever possible (e.g. energy mixes for China). Informal } \\
\text { sector could not be captured, thus leading to expected health impact } \\
\text { underestimation. }\end{array}$ & 100 & 0 & 0 \\
\hline $\mathrm{CN}-2$ & $\begin{array}{l}\text { Incineration of OPV modules is assumed following the general increase of } \\
\text { incineration in China. }{ }^{29-31} \text { Same incineration technology as in Europe } \\
\text { considered although this assumption is not valid. Airborne emissions of dioxins } \\
\text { were adjusted to reported emissions from Chinese incinerators. }{ }^{c}\end{array}$ & 0 & 100 & 0 \\
\hline $\mathrm{CN}-3$ & $\begin{array}{l}\text { An average mix representative of municipal solid waste (MSW) is considered } \\
\text { and assumed to represent a large and diffuse deployment of OPV in China. In }\end{array}$ & 17 & 22 & $21 / 40^{\mathrm{a}}$ \\
\hline CN-4 & $\begin{array}{l}\text { the absence of publicly available data, a literature review was conducted to } \\
\text { develop four average mixes that includes uncertainties in the incineration and } \\
\text { informal recycling rates (combining low and high ranges for each rate). }\end{array}$ & 38 & 22 & $21 / 19^{\mathrm{a}}$ \\
\hline CN-5 & $\begin{array}{l}\text { Recycling and incineration are modelled as in CN- } 1 \text { and CN-2, respectively. } \\
\text { Landfilling of PET is assumed for the landfilling of OPV modules, with two }\end{array}$ & 17 & 30 & $17 / 36^{\mathrm{a}}$ \\
\hline CN-6 & $\begin{array}{l}\text { different adjustments to distinguish (1) landfill with treatment of leachate and } \\
\text { (2) landfills with no leachate treatment and open dumps. }{ }^{d}\end{array}$ & 38 & 30 & $17 / 15$ \\
\hline
\end{tabular}

a More details about the modelling of the scenarios can be found in ESI-Methods†. 'REC': recycling, 'INC': incineration, 'L’: landfill (with leachate treatment), 'OD’: open dumps (and landfill without leachate treatment).

${ }^{\mathrm{b}}$ The informal sector and in general the recycling centres in China should be adapted with respect to emission factors and specific exposure situations (e.g. worker exposure). Different health impacts would thus be expected, but present knowledge in LCI and LCIA do not allow such differentiated modelling, hence it is modelled as normal situation (similar to European conditions, but with significantly lower plant efficiencies for incinerators compared to Denmark). Underestimation of impacts is therefore expected.

${ }^{\mathrm{c}}$ Stoker and fluidised bed technologies are used for incinerators in China whereas grate incinerators are in use in Europe. The ecoinvent database only covers the latter technology; hence it was selected as a proxy. Efficiencies, slag contents and air pollution control (APC) are thus expected to be different. Only dioxin emissions were adapted using reported values from Themelis et al. ${ }^{32}$

${ }^{\mathrm{d}}$ In landfills with treatment of leachate, the amount of silver is corrected to match the content of silver of the solar cells, and a distinction between short-term and long-term emissions is performed with the allocation of $1 \%$ and $99 \%$ of emissions, respectively. ${ }^{22,23}$ In landfill with no leachate treatment or open dumps, the amount of silver is corrected to match the silver content in the OPV modules and no long-term emissions are assumed (all emissions of heavy metals are considered as normal emissions).

\subsection{Life cycle impact assessment}

The assessment was performed using the ILCD life cycle impact assessment (LCIA) methodology v.1.5. ${ }^{18,33}$ It allows characterisation of all relevant impact categories, including climate change, stratospheric ozone depletion, photochemical ozone formation, acidification, terrestrial eutrophication, freshwater eutrophication, marine eutrophication, chemical pollution impacting freshwater ecosystems (termed 'freshwater ecotoxicity' in the following), chemical pollution impacting human health via carcinogenic effects (termed 'human toxicity, cancer effects') and non-carcinogenic effects (i.e. 'human toxicity, non-cancer effects'), respiratory inorganics caused by particulate matters (i.e. 'particulate matters'), ionizing radiation, land use, water 

perspectives. Energy and Environmental Science 8, 2537-2550. DOI: 10.1039/C5EE01763G.

resource depletion, resource depletion (metals and fossils). For a sensitivity check, a different LCIA methodology was additionally used, i.e. Recipe 2008 midpoint, hierarchist. ${ }^{34}$ Normalisation was also performed wherever relevant. Normalisation allows quantifying the magnitude of each impact relative to a common reference situation and enables further comparison across impact categories when including weighting of the impacts (either with equal weights if no weighting factors are applied or using specific weighting factors per impact category). ${ }^{35}$

\subsection{Analysed scenarios}

To address the goals of the study, a total of nine parameters were made to vary in the current study -see Table 3. This led to the definition of 28 scenarios (see complete list in Table SM20 in ESI-Methods).

The baseline scenario has been set to represent the OPV solar park in Denmark, with the materials composition as currently in place and with the default disposal scenario for Denmark (i.e. recycling of the OPV modules; see Section 2.3.3). That baseline scenario serves as basis to provide the LCI for a solar park. The parameters behind the other 27 scenarios can be categorised in 4 groups: (1) uncertainty-related parameters relating to modelling uncertainties, primarily the disposal scenarios of the OPV modules in Denmark and China; (2) eco-design-related parameters that include scenarios varying the type of insulator materials and explorative scenarios with inclusion of lifetime improvements and efficiency increases; (3) location-based parameters that focus on assessing the performances of the solar park as a function of the location of the manufacturing and installation sites in Denmark and China (direct comparisons DK-DK and $\mathrm{CN}-\mathrm{CN}$, and effects of exporting or outsourcing from a Danish perspective).

Table 3. Parameters and corresponding model settings included in the assessment (total of 28 scenarios, including baseline). ${ }^{\mathrm{a}}$

\begin{tabular}{|c|c|c|c|c|c|c|c|}
\hline \# Scenario & $\begin{array}{l}\text { Sensitivity } \\
\text { parameter }\end{array}$ & $\begin{array}{c}\text { Manufacturing } \\
/ \text { Installation } \\
\text { country } \\
\end{array}$ & $\begin{array}{l}\text { Disposal } \\
\text { route }\end{array}$ & Insulator & $\begin{array}{c}\text { Insulator } \\
\text { disposal }\end{array}$ & $\begin{array}{c}\text { Wood } \\
\text { disposal }\end{array}$ & $\begin{array}{c}\text { PCE / } \\
\text { lifetime }\end{array}$ \\
\hline 1 & Baseline & DK/DK & DK-1 & PET & $\mathrm{RE}$ & $\mathrm{RE}$ & $\begin{array}{l}1 \% / \\
1.5 \mathrm{yrs}\end{array}$ \\
\hline $2-3$ & $\begin{array}{l}\text { Disposal of OPV } \\
\text { modules } \\
\text { (Denmark) }\end{array}$ & DK/DK & DK-2/3 & PET & $\mathrm{RE}$ & $\mathrm{RE}$ & $\begin{array}{l}1 \% / \\
1.5 \mathrm{yrs}\end{array}$ \\
\hline 4 & $\begin{array}{l}\text { Disposal of } \\
\text { insulators and } \\
\text { wood structure }\end{array}$ & DK/DK & DK-1 & PET & IN & IN & $\begin{array}{l}1 \% / \\
1.5 \mathrm{yrs}\end{array}$ \\
\hline $5-12$ & $\begin{array}{l}\text { Type of insulator } \\
\text { material }^{\text {a }}\end{array}$ & DK/DK & DK-1 & $\begin{array}{l}\text { PE, PVC, PP, PS, } \\
\text { PUR, PC, PMMA, } \\
\text { GLASS FIBER }\end{array}$ & $\mathrm{RE}$ & $\mathrm{RE}$ & $\begin{array}{l}1 \% / \\
1.5 \mathrm{yrs}\end{array}$ \\
\hline $13-16$ & $\begin{array}{l}\text { Lifetime of OPV } \\
\text { modules }\end{array}$ & DK/DK & DK-1 & PET & $\mathrm{RE}$ & $\mathrm{RE}$ & $\begin{array}{l}1 \% / \\
1.5 \text { to } 5 \\
\text { years }\end{array}$ \\
\hline $17-20$ & $\begin{array}{l}\text { Efficiencies of the } \\
\text { OPV modules }\end{array}$ & DK/DK & DK-1 & PET & $\mathrm{RE}$ & $\mathrm{RE}$ & $\begin{array}{l}1 \% \text { to } 5 \% / \\
1.5 \text { yrs }\end{array}$ \\
\hline 21,22 & $\begin{array}{l}\text { Exporting/outsour } \\
\text { cing of solar park }\end{array}$ & $\begin{array}{l}\text { DK/CN } \\
\text { CN/DK }\end{array}$ & $\begin{array}{l}\text { CN-1 / DK- } \\
1\end{array}$ & PET & $\mathrm{RE}$ & $\mathrm{RE}$ & $\begin{array}{l}1 \% / \\
1.5 \mathrm{yrs}\end{array}$ \\
\hline 23 & $\begin{array}{l}\text { Location of the } \\
\text { solar park }\end{array}$ & $\mathrm{CN} / \mathrm{CN}$ & $\mathrm{CN}-1$ & PET & $\mathrm{RE}$ & $\mathrm{RE}$ & $\begin{array}{l}1 \% / \\
1.5 \mathrm{yrs}\end{array}$ \\
\hline $24-28$ & $\begin{array}{l}\text { Disposal of OPV } \\
\text { modules (China) }\end{array}$ & $\mathrm{CN} / \mathrm{CN}$ & $\begin{array}{l}\mathrm{CN}-2-\mathrm{CN}- \\
6\end{array}$ & PET & $\mathrm{RE}$ & $\mathrm{RE}$ & $\begin{array}{l}1 \% / \\
1.5 \mathrm{yrs}\end{array}$ \\
\hline
\end{tabular}

${ }^{\mathrm{a}} \mathrm{RE}$ refers to recycling, IN to incineration, DK is Denmark and CN is the label for China.

b The selection of the plastics as insulating materials was made using specifications of a surface resistivity greater than $10^{12} \Omega /$ sq (ohms per square). Eight alternatives to PET (polyethylene terephthalate, currently used) are thus included, 

perspectives. Energy and Environmental Science 8, 2537-2550. DOI: 10.1039/C5EE01763G.

for which life cycle inventories are available in ecoinvent: PE (polyethylene), PVC (polyvinyl chloride), PP (polypropylene), PS (polystyrene), PUR (polyurethane), PC (polycarbonate), PMMA (polymethyl methacrylate).

\section{Results and discussion}

\subsection{Life cycle inventory of a $6 \mathrm{~kW}$ solar park}

The complete details of the life cycle inventory modelling of the solar park are documented in ESI-Methods and Tables SM2- SM15 in ESI-1. These include all inputs and outputs from each process along the life cycle of the solar park. Transparency was sought as much as possible to allow LCA practitioners to use these data in future studies. In addition, an aggregated life cycle inventory, i.e. gathering all resource consumptions and pollutant emissions over the entire life cycle of the solar park, was derived for the baseline scenario and is presented in ESI-2. The format of this data set, scaled to the supply of $1 \mathrm{kWh}$ of electricity to Danish grid (baseline scenario), allows direct import into LCA software SimaPro. In addition to the special features of this data set (baseline scenario, see Section 2.5), the practitioners should be aware that the data associated with the manufacturing of the solar park originate from a pilot-scale plant. Possible upscaling effects may thus occur when considering a full deployment on the market, thus affecting the materials and energy requirements as well as the emission intensities for the better. It is assumed that the data presented here is the worst case scenario when compared to a further upscaled scenario.

\subsection{Environmental performances of a Danish 6 kW OPV solar park}

\subsubsection{Environmental profile}

Table S3 in ESI-1 shows the characterised impact scores for each impact category for the baseline scenario. The interpretation of the indicator units is difficult to make as such with the exception of climate change. It can thus be observed that the Danish solar park in the baseline scenario embeds $0.69 \mathrm{~kg}-\mathrm{CO}_{2} \mathrm{eq} / \mathrm{kWh}$ produced. This result falls more in the range of fossil-based technologies (e.g. $0.99 \mathrm{~kg}-\mathrm{CO}_{2} \mathrm{eq} / \mathrm{kWh}$ from coal and $0.53 \mathrm{~kg}-\mathrm{CO}_{2} \mathrm{eq} / \mathrm{kWh}$ from natural gas in Denmark ${ }^{24}$ than renewable technologies $\left(0.016 \mathrm{~kg}-\mathrm{CO}_{2} \mathrm{eq} / \mathrm{kWh}\right.$ from off-shore wind in Denmark, $0.11 \mathrm{~kg}-\mathrm{CO}_{2} \mathrm{eq} / \mathrm{kWh}$ from a $570 \mathrm{~kW}$ open ground power plant in Germany $^{24}$ ). This high score is primarily expected to stem from the pilot scale employed in this study (see Section 3.1). What is significant is that the values are comparable to established technologies at a much larger scale.

To compare across impact categories and identify large impacts, normalisation and weighting can be performed. ${ }^{35}$ Assuming an equal weight across impact categories, Table S4 in ESI-1 shows that the environmental profile is largely dominated by resource depletion followed by toxicity impacts on human health and ecosystems. This finding is insensitive to the inclusion or exclusion of long-term emissions, which are controversial in the scientific community and have important consequences on the absolute scores for toxicity impacts ${ }^{36}$ and to the change of the LCIA methodology, which may also alter the conclusions of LCA studies $^{37}$-see Table S4 in ESI-1. In the latter sensitivity check, the impact indicator scores obtained using ReCiPe show that toxic impacts largely dominate, and to a lesser extent, metal depletion and freshwater eutrophication. The largely dominating normalised scores for toxic impacts are typical in LCA studies and partially stem from an incomplete coverage of the thousands of chemicals, which may potentially be released to the environment, in life cycle inventories and LCIA methodologies. ${ }^{38}$ Therefore, assuming equal weighting across impact categories, the overall environmental profile of the solar park suggests that metal 

perspectives. Energy and Environmental Science 8, 2537-2550. DOI: 10.1039/C5EE01763G.

depletion is a critical environmental problem along with the toxicity impacts exerted by chemical releases and freshwater eutrophication.

\subsubsection{OPV modules as the largest contributions to the total impact}

Hotspots in the life cycle of the solar park (baseline scenario) can be investigated by conducting process and substance contribution analyses, i.e. identifying which processes and substances are large contributors to the different impact categories. Fig. 3 shows the distribution of impacts by life cycle stages and by components. The environmental benefits from the disposal stage can be observed, counterbalancing the impacts from the production stage with contributions of $40-75 \%$ across impact categories. The avoided materials and energy production from the recovery processes are responsible for those benefits.

From all components of the system, only three present a significant contribution. The aluminium mounting wagon, the cabling and the inverter are associated with negligible impacts when considering the whole environmental burden of the solar park. In contrast, the OPV modules and, to a lesser extent, the wood structure and the insulator, account for all impacts although variations in their distributions exist depending on the impact category (see Fig. 3). All three components are thus included in the eco-design exercise undertaken in Section 3.3.

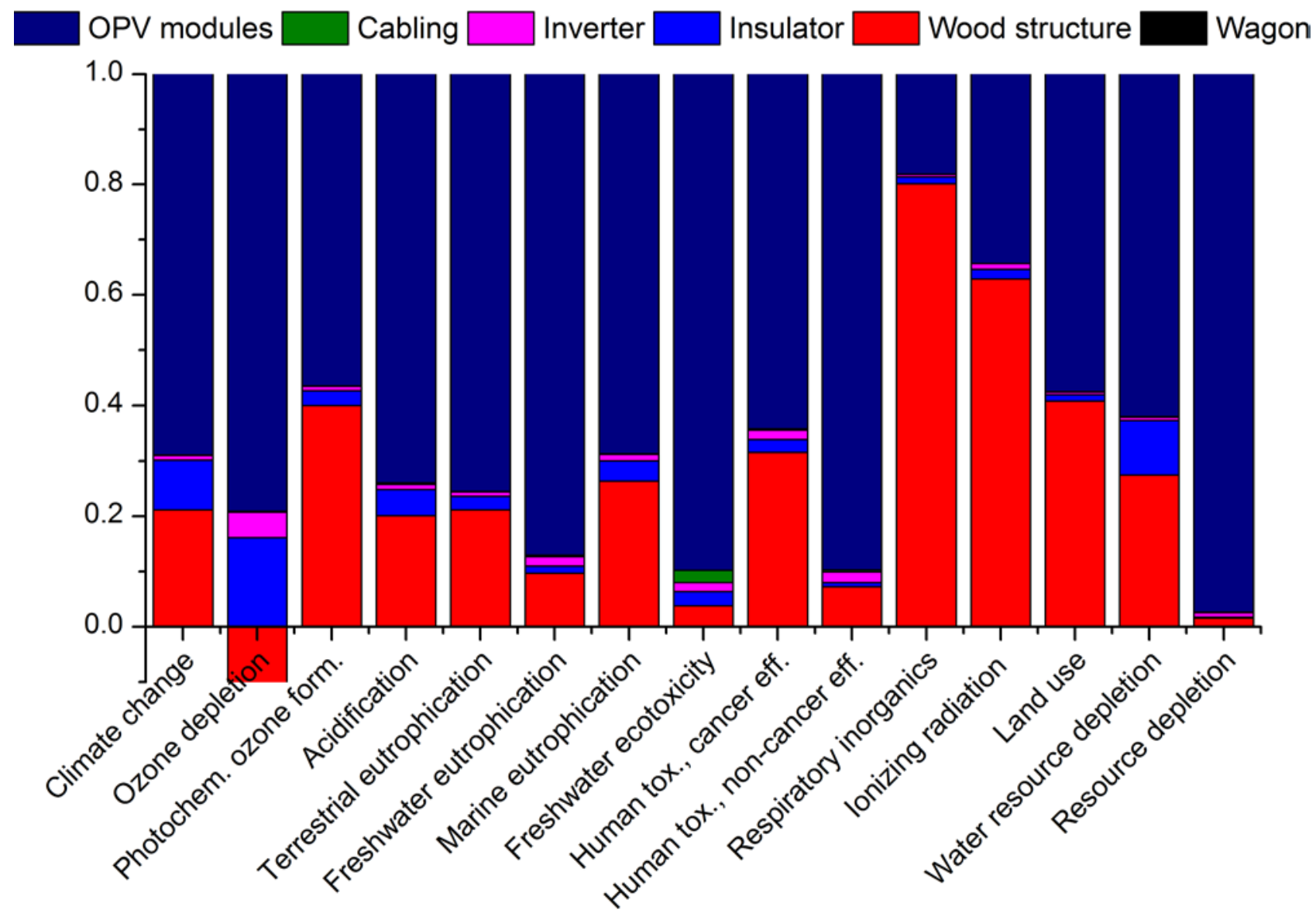



perspectives. Energy and Environmental Science 8, 2537-2550. DOI: 10.1039/C5EE01763G.

Fig. 3. Contribution of the elements of the solar park to the selected ILCD impact categories. Wood structure gives negative results for ozone due to the selected disposal that avoids the production of virgin wood. Further details found in Supplementary Information.

The OPV module impact contributions range from 25\% (for human toxicity, cancer effects) to nearly $100 \%$ (resource depletion, freshwater eutrophication). For nearly all impact categories, the production of silver is responsible for these impacts. Despite the recycling of silver (ca. $72 \mathrm{wt} \%$ overall recovery), the required quantities of this scarce metal for the electrode manufacture are a critical aspect explaining the high score for the resource depletion impact indicator (see Section 3.2.1). The mining of the silver is also responsible for a number of other impacts, such as the sulfidic tailing, the sulfidic wastes and acid mine waters from the extraction of silver, that cause more than $90 \%$ of the freshwater eutrophication of the system life cycle. Therefore, other types of electrode materials should be sought or highly efficient recycling schemes for silver should be developed. Replacing silver by a non-metal electrode should lead to carbon footprints comparable to that of silicon modules mounted on an open-ground plant (e.g. $0.11 \mathrm{~kg} \mathrm{CO}_{2} \mathrm{eq} / \mathrm{kWh}^{24}$ ). Research works are currently on-going to undertake that recommendation. ${ }^{39}$ For example, shifting from a silver-based electrode to a carbon-based one would induce a 2-fold reduction in the carbon footprint of the entire solar park (from 1.1 to $0.51 \mathrm{~kg}-\mathrm{CO}_{2} \mathrm{eq} / \mathrm{kWh}^{39}$ ). Such large decreases would be visible for all other impact categories, with decreasing factors ranging between 8 and $81 .^{39}$ Other alternative non-metal-based materials should therefore also be investigated. In parallel to these initiatives, reductions in the large contributions from the OPV modules can be achieved through the increase of their lifetime and efficiencies; potential effects on the environmental performances of the system are tested through a number of scenarios (see Section 3.3).

\subsubsection{Benefits of recycling the solar park}

Fig. 4 illustrates the environmental performances of the Danish solar park under the different waste management scenarios, indexed on the baseline scenario (scaled to $100 \%$ for each impact category). It is observed that the incineration pathway (despite providing 30\% back of the cumulative energy demand needed for the manufacturing of the solar park, in the form of electricity and heat) leads to larger impacts than the recycling route. The increases in factors range from $46 \%$ to $820 \%$ depending on the impact category and they are explained by the absence of the environmental benefits brought along by recovering PET and silver materials, which are not compensated by the additional gain of recovering slightly more energy when incinerating the entire OPV modules without a recycling treatment. The average scenario is primarily governed by incineration (ca. 70\%) that hence also leads to larger impacts than the baseline scenario. 


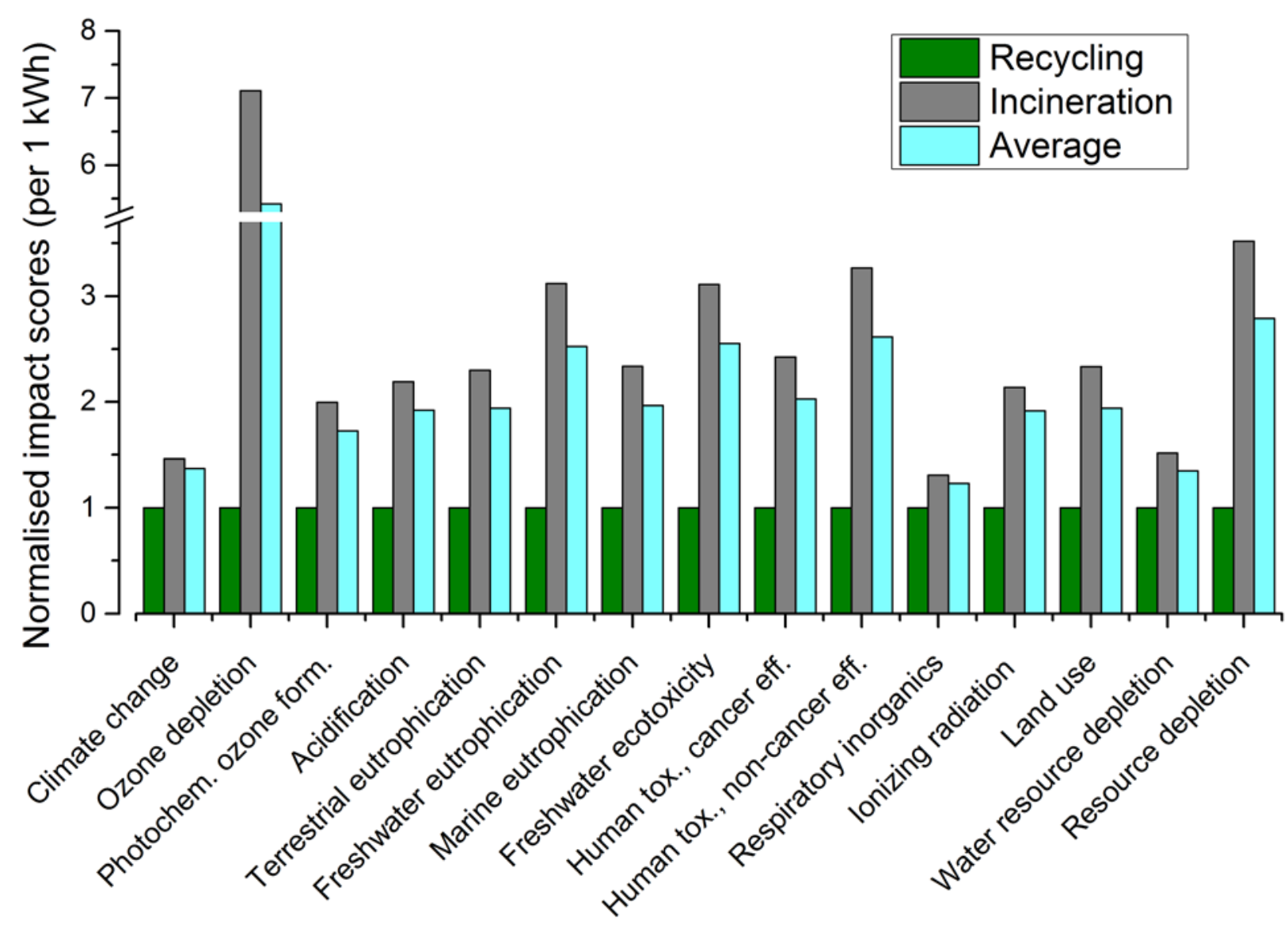

Fig. 4.Comparisons of the three disposal scenarios on the environmental performances for the Danish solar park (indexed on baseline scenario, DK-1 taken as 100\%). See Table S3 in ESI-1 for detailed impact scores.

The same pattern is observed for China, where the recycling-based scenario (i.e. CN-1) provides the best environmental profiles compared to the five other scenarios -see Table S11 in ESI-1. Ratios comprised between 1.3 and 3.5 are observed between the recycling-based $(\mathrm{CN}-1)$ and incineration-based scenarios $(\mathrm{CN}$ 2) depending on the impact category. Average scenarios CN-4 and CN-6, which include the highest recycling rates (see Table 2 in Section 2.3.3), thus rank just behind the baseline for China (DK-1), with factors of 1.1-2.4 across impact categories.

Therefore, assuming equally-distributed uncertainties between the compared disposal scenarios, these findings support the recommendation to promote the setting of an efficient recycling system for solar parks. Several mechanisms can facilitate such a setting, including putting the responsibility on the manufacturer, retailer or the operator. In the lifetime of a solar park, OPV modules have to be replaced every few years (ca. 1.5 years with current technology level). Because of their special manufacturing properties (roll-to-roll), they can easily be dismantled ${ }^{9}$ and replaced on-site by the manufacturer, retailer or operator. If there is a lack of economic motivation for manufacturers to voluntarily take responsibility for the recycling of the solar modules, appropriated incentives should be regulated. ${ }^{40}$ Liability on one of those actors, who can also have financial incentives for implementing such a take-back system, should thus be easily implementable. 

perspectives. Energy and Environmental Science 8, 2537-2550. DOI: 10.1039/C5EE01763G.

\subsection{Ecodesign of the Danish OPV solar park}

Taking the baseline scenario for Denmark described in Section 3.1 and 3.2 (with disposal scenario DK-1), four parameters are made to vary for ecodesign purposes: the type of insulator materials, the disposal of insulators and wood structure, the lifetime and efficiencies of the OPV modules -see Section 2.5. Each is described in the subsequent sections.

\subsubsection{Looking for low-impact insulator material}

As described in Section 3.2.2, the production of the insulator has a relatively major contribution to some impacts. In particular, Fig. 5 illustrates that, considering the manufacture of the solar park, insulators account for ca. $35 \%$ of the water use impacts and for ca. $20 \%$ of the impacts on climate change and freshwater ecotoxicity (and human toxicity - cancer effects to a lesser extent). For eco-design purposes, these impact categories should therefore be targeted to allow for meaningful reduction of the environmental impact of the solar park over its life cycle.

Table 4 shows the impact scores for the eight alternatives scaled to the results for the baseline scenario (use of PET). A color-coding is used to indicate the ranking of the alternatives for each individual impact category (red: least environmentally-preferable; green: most environmentally-preferable). A first observation of the scores reveals that most alternatives range close to each other. The uncertainties inherent to the impact assessment methods and the analysed systems therefore do not allow for claiming definite superiority of one alternative over another. It should be stressed that all materials are considered to be recycled with the same recovery grade. A differentiation in the recycling of the different plastics or the consideration of other types of waste management could therefore significantly alter the ranking presented in Table 4, e.g. incineration of PVC is known to lead to emissions of dioxins, thus impacting ecosystems and human health. ${ }^{41,42}$

Regardless of such possible alterations, the ranking suggests that PVC may perform environmentally better than the other alternatives in nearly all impact categories but water use (and freshwater ecotoxicity). For freshwater ecotoxicity, all alternatives rank similar to PET. A trade-off thus emerges as contrasting trends are observed for the PVC system between climate change (performing best), freshwater ecotoxicity (performing equally) and water use (performing worst). If climate change was prioritised over water use, PVC could then be selected as a preferable alternative. If a trade-off cannot be solved by the weighting of these three impact categories, a compromise could be reached by selecting polystyrene or polyurethane as they are consistently associated with lower impacts than PET. The investigation of other insulator materials such as biodegradable plastics could also bring further benefits, e.g. reductions of the carbon footprint are expected to be ca. $30 \%$ when substituting PET by a commercial starch derivative. ${ }^{43}$

Table 4. Normalized impact scores for the Danish solar park life cycle with different insulator materials (indexed on baseline scenario with PET).

\begin{tabular}{lccccccccc}
\hline & PET & PVC & PE & PC & GRF & PMMA & PP & PS & PUR \\
\hline Climate change & 1 & 0.72 & 0.96 & 1.05 & 1.07 & 0.93 & 0.97 & 0.91 & 0.92 \\
& 1 & 0.96 & 0.87 & 0.87 & 1.56 & 0.87 & 0.86 & 0.86 & 0.85 \\
$\begin{array}{l}\text { Ozone depletion } \\
\begin{array}{l}\text { Human toxicity, cancer } \\
\text { effects }\end{array}\end{array}$ & 1 & 0.92 & 0.98 & 1.02 & 1.06 & 0.99 & 0.99 & 0.98 & 0.98 \\
$\begin{array}{l}\text { Human toxicity, non-cancer } \\
\text { effects }\end{array}$ & 1 & 0.62 & 0.96 & 1.02 & 1.05 & 1.03 & 0.98 & 0.95 & 0.96 \\
Respiratory inorganics & 1 & 0.89 & 0.98 & 1.01 & 1.03 & 0.97 & 0.99 & 0.98 & 0.98 \\
\hline
\end{tabular}



perspectives. Energy and Environmental Science 8, 2537-2550. DOI: 10.1039/C5EE01763G.

\begin{tabular}{llllllllll}
\hline Ionizing radiation & 1 & 0.98 & 0.99 & 1.00 & 1.01 & 1.00 & 0.99 & 0.99 & 0.99 \\
$\begin{array}{l}\text { Photochemical ozone } \\
\text { formation }\end{array}$ & 1 & 0.88 & 0.97 & 1.01 & 1.04 & 0.94 & 0.98 & 0.96 & 0.98 \\
Acidification & 1 & 0.93 & 0.99 & 0.99 & 1.01 & 0.98 & 0.99 & 0.98 & 0.98 \\
Terrestrial eutrophication & 1 & 0.47 & 0.98 & 1.01 & 1.02 & 0.97 & 0.99 & 0.98 & 0.98 \\
Freshwater eutrophication & 1 & 0.97 & 1.00 & 1.00 & 1.01 & 0.99 & 1.00 & 0.99 & 0.99 \\
Marine eutrophication & 1 & 0.64 & 0.99 & 1.03 & 1.01 & 1.00 & 0.99 & 0.99 & 0.99 \\
Freshwater ecotoxicity & 1 & 0.99 & 0.99 & 0.99 & 0.99 & 0.99 & 0.99 & 0.98 & 0.98 \\
Land use & 1 & 0.99 & 0.99 & 0.99 & 1.01 & 0.99 & 0.99 & 0.99 & 0.99 \\
Water resource depletion & 1 & 1.67 & 0.89 & 0.94 & 1.01 & 0.90 & 0.91 & 0.91 & 0.91 \\
Resource depletion & 1 & 1.00 & 1.00 & 1.00 & 1.00 & 1.00 & 1.00 & 1.00 & 1.00 \\
\hline
\end{tabular}

${ }^{\bar{a}}$ Impact targeted by eco-design incentives are highlighted in bold. Color-coding is used to indicate the ranking of the alternatives to PET (polyethylene terephthalate, currently used) are thus included, for which life cycle inventories are available in ecoinvent: PVC (polyvinyl chloride), PE (polyethylene), PC (polycarbonate), GRF (glass reinforced fibre), PMMA (polymethyl methacrylate), PP (polypropylene), PS (polystyrene), PUR (polyurethane).

\subsubsection{What disposal routefor the wood structure and plastic insulator?}

To further investigate the role of the wood structure and the insulator in the environmental burden (see Section 3.2.2), an alternative disposal scenario - incineration - to the assumed default recycling was considered (See Table 2 in Section 2.5). Fig.5 shows the comparisons of the environmental profiles between these two disposal systems. The incineration scenario is associated with larger impacts in nearly all categories but respiratory impacts caused by inorganics (respiratory inorganics) and ionising radiation, both not being the focus of the ecodesigning of the wood structure and insulator. As a consequence, the recycling of these wood and plastics materials is strongly advocated. These findings are also in line with previous studies showing benefits of recycling over incineration for those waste fractions, e.g. Laurent et al. and Michaud et al. ${ }^{44,45}$ 


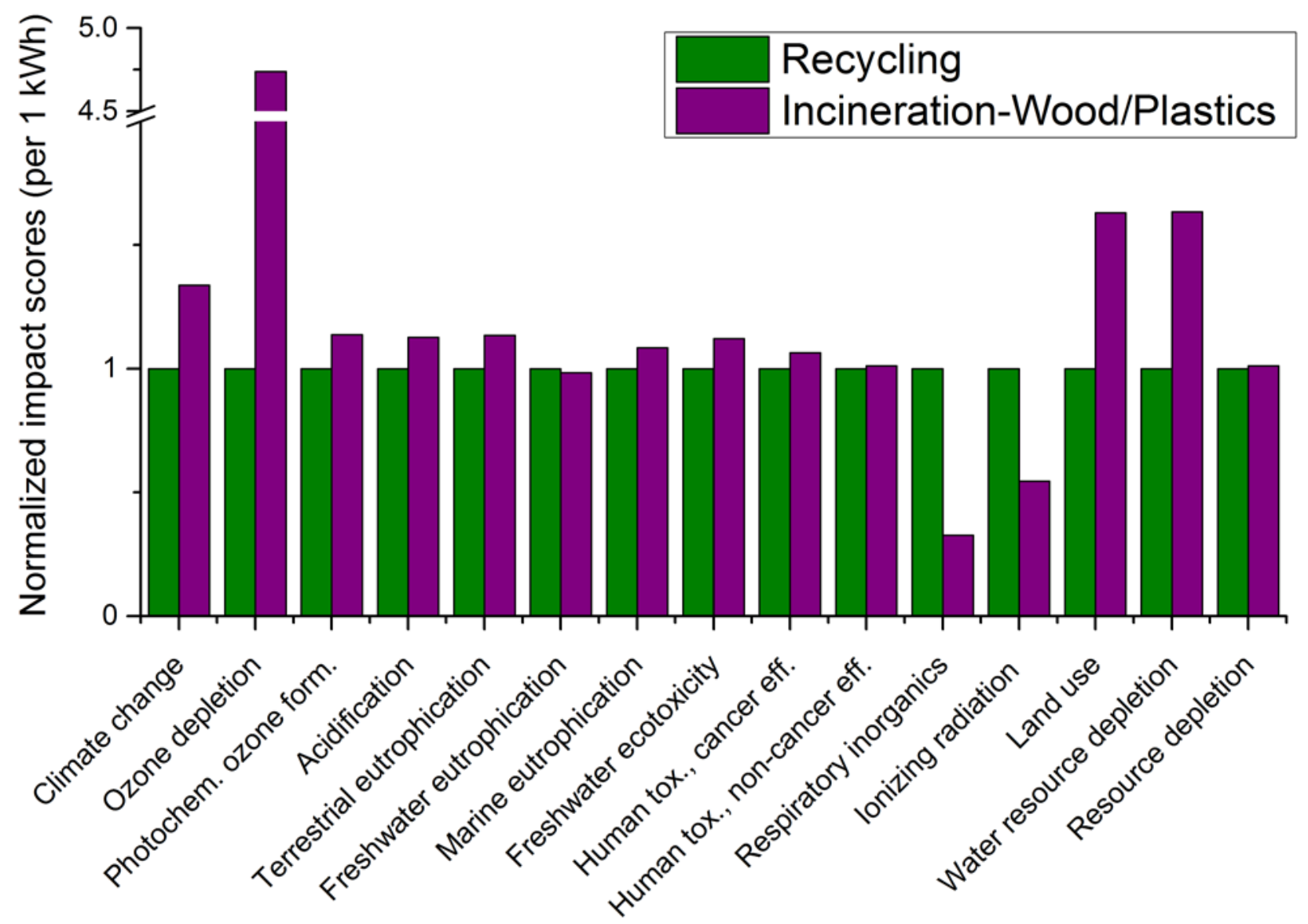

Fig. 5. Normalised impact scores for the Danish solar park life cycle with recycling and incineration scenarios for wood structure and insulator (indexed on recycling scenario).

\subsubsection{Increasing lifetime and efficiency can bringsignificant impact reductions}

Fig.6 shows the impact score results obtained for the Danish solar park when gradually increasing the lifetime of the OPV modules from 1.5 years to 5 years. An exponential trend is observed with each impact score tending towards an asymptote. The levels of these asymptotes are dictated by the respective contribution of the OPV modules to the environmental burden of the Danish solar park, and are thus specific to each impact category. Because the lifetime of the OPV modules only has consequences on the environmental performances of the OPV modules, its increase can only affect the share of total impacts caused by the OPV modules (see distributions in Fig. 3 in Section 3.2.2). This explains why reductions are relatively minor for respiratory inorganics, where OPV modules are only responsible for $18 \%$ of the total impact. In contrast, large reductions are observed for resource depletion because OPV modules account for $97 \%$ of the total impact of the solar park. Table S2 in ESI-1 provides the exact shares of impacts caused by the OPV modules, i.e. the values of the asymptotes for the trends observed in Fig. 6 . With a lifetime of 5 years, which is the maximum lifetime undertaken in the study, the environmental impacts associated with the OPV modules are thus estimated to be approximately halved for all impact categories, with decreasing ratios of ca. 3 times. 


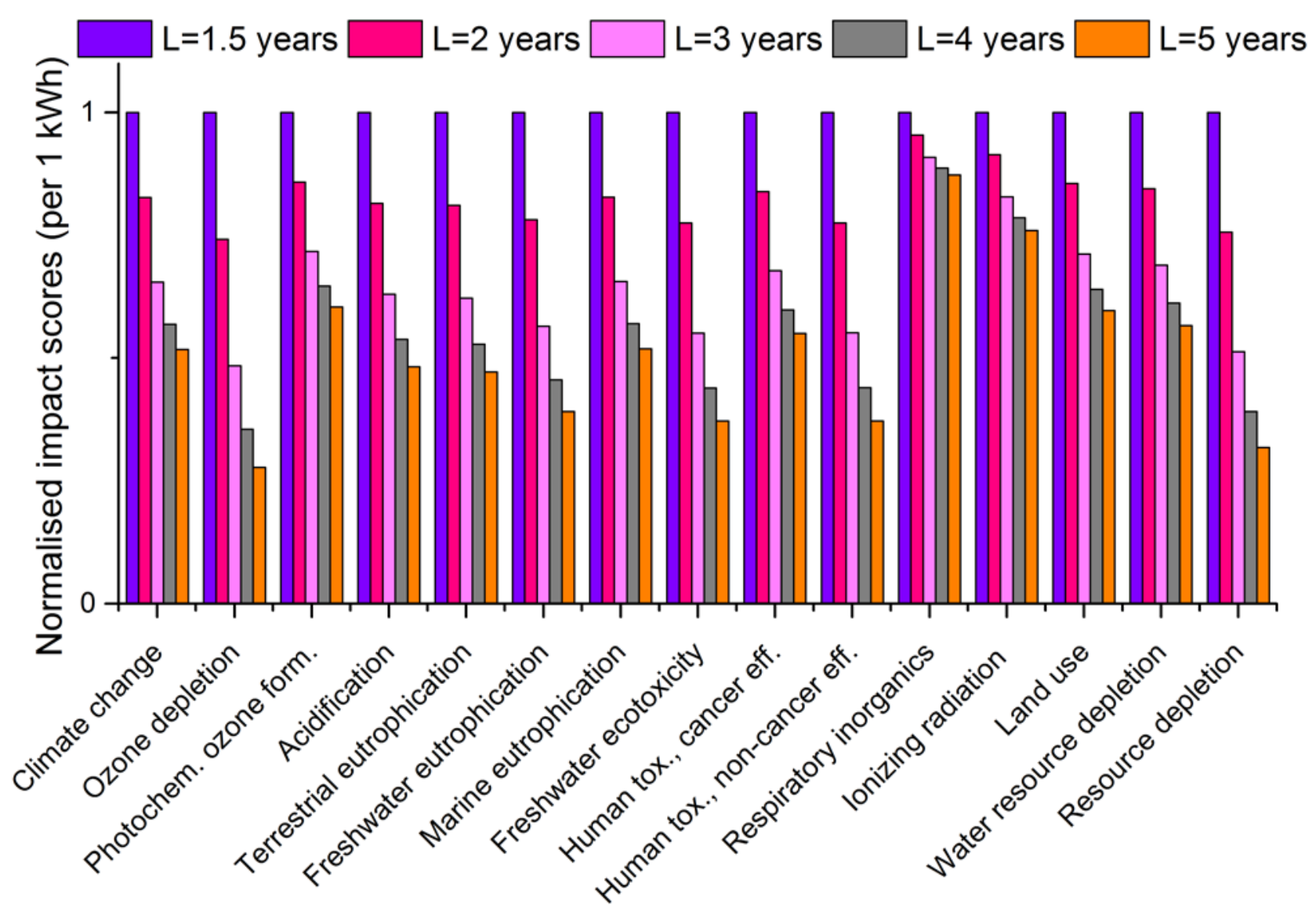

Fig. 6. Normalised impact results for the Danish solar park life cycle with different lifetime of OPV modules (indexed on impacts for lifetime of 1.5 years).

When increasing the efficiencies of the modules (PCE), the required area of solar cells is decreased to fulfil the same functional unit as defined in Section 2.2. The inputs and outputs of the whole system are thus downscaled in an inversely proportional manner to the module efficiencies. As a consequence, the environmental burden of the solar park reacts linearly to a gain in efficiency. An increase of the efficiency from $1 \%$ to $5 \%$ thus leads to a decrease in the overall impact of the solar park by a factor of 5 . On-going works currently focus on increasing the efficiencies of OPV modules, which may therefore dramatically reduce the environmental burden and bring it to the level of other renewables. A reduction of a factor of 5 when the efficiency is $5 \%$, can bring the climate change impacts down to $0.14 \mathrm{~kg}-\mathrm{CO}_{2} \mathrm{eq} / \mathrm{kWh}$. This is comparable to other photovoltaic technologies on the market.

\subsection{Effect of location: Are there benefits from outsourcing and exporting?}

The effect of location was investigated by taking China as an alternative country for the manufacturing and installation of the solar park. This choice was motivated by the different solar irradiation and by the different technology and energy landscapes, as opposed to Denmark. Four situations can therefore be compared whether manufacturing and installation of the solar parks take place in Denmark or China (see Table 5). The manufacturing sites dictate the draw on specific background processes such as transportation and electricity supply, which are adapted to either China or Denmark in the study. The installation sites determine the area of solar cells required to meet the functional unit (dependent on the irradiation; see Section 2.2 and 2.3). The 

perspectives. Energy and Environmental Science 8, 2537-2550. DOI: 10.1039/C5EE01763G.

benefits of integrating the geographical factor into a more global approach to PV policy and market regulations, offer the possibility to find the optimum combination to avoid impacts and in particular $\mathrm{CO}_{2}$ emissions. ${ }^{46}$ Additionally the type of waste management systems to be considered for the disposal of the solar park components must be included. For simplicity, the recycling-based scenarios are considered for both China (CN-1) and Denmark (DK-1) in the following discussion. As indicated in Section 3.2.3, these disposal scenarios lead to the least environmental impacts for the solar park.

Table 5. Four comparative scenarios for Denmark and China depending on location of manufacturing and installation sites.

\begin{tabular}{|c|c|c|}
\hline \multirow[b]{2}{*}{ Manufacturing } & \multicolumn{2}{|c|}{ Installation } \\
\hline & Denmark & China \\
\hline \multirow[t]{2}{*}{ Denmark } & DK-DK & DK-CN \\
\hline & $\begin{array}{l}\text { (baseline scenario } \\
\text { for Denmark; see } \\
\text { Section 3.1) }\end{array}$ & $\begin{array}{l}\text { (exporting from } \\
\text { Denmark) }\end{array}$ \\
\hline China & $\begin{array}{l}\text { CN-DK } \\
\text { (outsourcing of } \\
\text { production from } \\
\text { Denmark) }\end{array}$ & $\begin{array}{l}\text { CN-CN } \\
\text { (baseline scenario } \\
\text { for China) }\end{array}$ \\
\hline
\end{tabular}

Impact scores obtained for the four scenarios are shown in Fig. 7. The comparisons between the DK-DK and CN-CN systems show that the solar park brings more environmental benefits per unit of electricity output in China than in Denmark (with domestic production and installation). With the exception of acidification, which is driven by the acid process from the recycling stage, all impacts are lower for China than for Denmark. For example, the climate change impacts are lowered from $0.68 \mathrm{~kg}-\mathrm{CO}_{2}$-eq $/ \mathrm{kWh}$ in Denmark to $0.48 \mathrm{~kg}-\mathrm{CO}_{2} \mathrm{eq} / \mathrm{kWh}$ in China. These differences are explained by the irradiation level, which is ca. $55 \%$ higher in China than in Denmark, thus inducing a lower requirement of solar park (i.e. lower solar cell area) for the same electricity output. This influence is also visible when the solar park is manufactured in Denmark and installed in China as this configuration brings similar results as when the solar park is manufactured in Denmark, thus indicating that the location of the manufacturing site is less important than that of the installation site. However, Fig. 7 also shows that the manufacturing of the solar park in Denmark is environmentally-preferable compared to a manufacturing in China (comparisons between CN-DK and DKDK, and DK-CN and CN-CN). As indicated in past studies on different technology fields, ${ }^{47}$ outsourcing the production of a Danish solar park in China is therefore not suitable from a strictly environmental point of view. Exporting the technology can however bring potentially large environmental benefits as the significant gains due to the irradiation could make the solar park more competitive with other renewable sources, e.g. wind technology. These findings also extend beyond the limited scope of China and Denmark as they can be generalised to other types of settings. To optimise the environmental performances of the solar park in its life cycle, the manufacture of the modules should be performed in a country with stringent emission standards and low-impact energy mixes (e.g. large share of renewables), while the deployment should take place in countries with higher irradiation. An effective system for recycling the OPV modules should also be established to minimise the impacts stemming from the end-of-life of the solar park (see Section 3.2.3). 


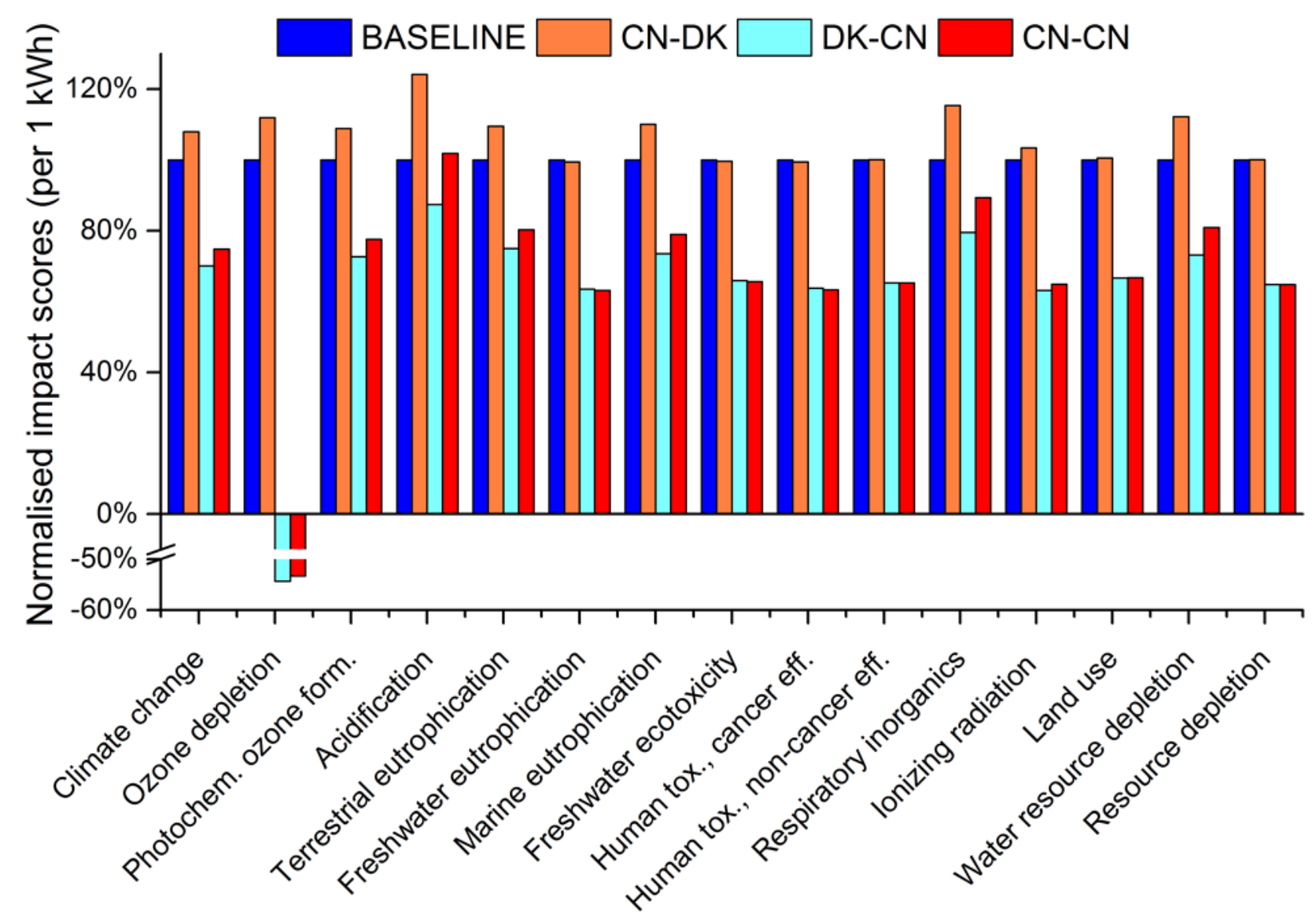

Fig. 7. Normalised impact scores for a solar park life cycle with locations of manufacturing and installation sites over Denmark (DK) and China (CN). Scores are normalised against those for Baseline (DK-DK) (scaled to 100\%). Baseline (DK-DK): solar park manufactured and installed in Denmark; CN-DK: solar park manufactured in China and installed in Denmark; DK-CN: solar park manufactured in Denmark and installed in China; CN-CN: solar park manufactured and installed in China. See Tables S10- S14 for further details.

\section{Conclusions and recommendations}

A complete aggregated life cycle inventory that gathers all resource consumptions and pollutant emissions over the entire life cycle of a $6 \mathrm{~kW}$ Danish solar park has been developed and made available. It is the first time that the entire life cycle of a solar park, veering all aspects from the manufacturing, installation, operation and decommission, are considered in a huge effort to improve the eco-design of the technology.LCA practitioners in the PV community are now able to use these data in future studies. Based on the extensive analysis of this system, we also propose a number of recommendations to (i) stakeholders in the PV field, including decision- and policy-makers, (ii) PV researchers or technology developers, and (iii) LCA practitioners in their assessment of environmental impacts from OPV technology.. Some of these recommendations have a global reach. In particulars findings from the CN-DK study suggest that configurations associated withthe most environmentally-attractive settings for manufacturing and deploying OPV-based solar parks can be determined globally. This can be used as a tool to map the locations of manufacturing, deployment and disposal that make OPV technologies the most competitive with regard to other electricity generation technologies. Table 6 summarises those and more recommendations derived from the study. 
Espinosa N., Laurent A., Krebs F.C., 2015. Ecodesign of organic photovoltaic modules from Danish and Chinese perspectives. Energy and Environmental Science 8, 2537-2550. DOI: 10.1039/C5EE01763G.

Table 6. Overall recommendations for moving towards low-impacts photovoltaic systems.

\begin{tabular}{|c|c|}
\hline Target audience & Recommendation \\
\hline $\begin{array}{l}\text { PV policy- and } \\
\text { stakeholders }\end{array}$ & $\begin{array}{l}\text { Regulate the management of the end-of-life of the OPV modules, } \\
\text { establishing/ensuring take-back systems to increase material recoveries,thus } \\
\text { reducing environmental impacts. Liability on the manufacturers or on the } \\
\text { operators should be implemented without providing a competitive advantage to } \\
\text { other forms of electricity production. } \\
\text { - Aim at anchoring the manufacturing of the solar park in countries with low } \\
\text { environmental impacts (e.g. with stringent emission standards, high technology } \\
\text { efficiencies, etc.) and at deploying it in countries with high irradiation to } \\
\text { maximise the environmental benefits of the PV technology. }\end{array}$ \\
\hline $\begin{array}{l}\text { PV researchers, } \\
\text { industry and } \\
\text { technology } \\
\text { developers }\end{array}$ & $\begin{array}{l}\text { Explore other electrode materials to avoid using scarce materials like silver, } \\
\text { which induces large environmental impacts and is responsible for most of the } \\
\text { environmental burden associated with the OPV solar park. } \\
\text { - Investigate other insulator/substrate plastic materials, which could bring further } \\
\text { benefits - e.g. biodegradable plastics to replace PET. } \\
\text { - Include the entire life cycle perspective when designing PV technology; in } \\
\text { particular considering potential disposal routes of the materials in the location of } \\
\text { the solar park. } \\
\text { - Provide LCA practitioners with real data from PV installations to improve the } \\
\text { quality of results and to reduce uncertainties of the studies. } \\
\text { Build open-access databases of high quality, based on real data. This action could } \\
\text { be shared with PEV stakeholders. On-going efforts are currently taken in OPV } \\
\text { field under EU COST Action StableNextSol. }\end{array}$ \\
\hline $\begin{array}{l}\text { LCA practitioners } \\
\text { (in PV field) }\end{array}$ & $\begin{array}{l}\text { - Apply the LCI provided in this study - with consideration of the uncertainties } \\
\text { associated with it, e.g. partial reliance on lab-scale/pilot-scale data. } \\
\text { - Perform foresight assessments to investigate the long-term environmental } \\
\text { benefits that OPV technologies could potentially bring (explore different settings } \\
\text { and locations). } \\
\text { - Build upon the recent methodological developments in the field of LCI and LCIA } \\
\text { to allow more accurate LCA studies of PV technologies, e.g. inclusion of spatial } \\
\text { differentiation in the impact assessment phase (LCIA), increased model } \\
\text { robustness and substance coverage at both LCI and LCIA levels, inclusion of } \\
\text { occupational exposure modules in the assessment of damages to human health, } \\
\text { inclusion of rare earth metals in resource depletion impact category (e.g. relevant } \\
\text { when comparing OPV and conventional PV technologies), etc. }\end{array}$ \\
\hline
\end{tabular}

\section{Acknowledgments}

N.E. and F.C.K acknowledge funding from the Danish Ministry of Science, Innovation and Higher Education under a Sapere Aude Top Scientist grant (no. DFF - 1335-00037A) and an Elite Scientist grant (no. 11-116028). All authors gratefully acknowledge M. Z. Hauschild for valuable contributions to the conception of the work. 
Espinosa N., Laurent A., Krebs F.C., 2015. Ecodesign of organic photovoltaic modules from Danish and Chinese perspectives. Energy and Environmental Science 8, 2537-2550. DOI: 10.1039/C5EE01763G.

\section{Notes and References}

$\dagger$ Electronic Supplementary Information (ESI) available: 1) ESI-1 containing Supplementary Methods (Figs. SM1- SM5; Tables SM1- SM 19) and Supplementary Results and Discussions (Figs. S1-S5; Tables S1-S14), 2) ESI-2 containing Table S15 in an electronic format.

1 A. L. Roes, E. A. Alsema, K. Blok and M. K. Patel, Prog. Photovolt. Res. Appl., 2009, 17, 372-393.

2 R. García-Valverde, J. A. Cherni and A. Urbina, Prog. Photovolt. Res. Appl., 2010, 18, 535-558.

3 N. Espinosa, R. García-Valverde, A. Urbina and F. C. Krebs, Sol. Energy Mater. Sol. Cells, 2011, 95, 1293-1302.

4 N. Espinosa, M. Hösel, D. Angmo and F. C. Krebs, Energy Environ. Sci., 2012, 5, 5117.

5 A. Anctil and V. Fthenakis, in Third Generation Photovoltaics, ed. V. Fthenakis, InTech, 2012.

6 C. J. M. Emmott, A. Urbina and J. Nelson, Sol. Energy Mater. Sol. Cells, 2012, 97, 14-21.

7 A. Anctil, C. W. Babbitt, R. P. Raffaelle and B. J. Landi, Prog. Photovolt. Res. Appl., 2013, 21, 15411554.

8 N. Espinosa, M. Hösel, M. Jørgensen and F. C. Krebs, Energy Environ. Sci., 2014, 7, 855.

9 R. R. Søndergaard, N. Espinosa, M. Jørgensen and F. C. Krebs, Energy Environ. Sci., 2014, 7, 1006.

10 N. Espinosa and F. C. Krebs, Sol. Energy Mater. Sol. Cells, 2014, 120, 692-700.

11 D. Yue, P. Khatav, F. You and S. B. Darling, Energy Environ. Sci., 2012, 5, 9163-9172.

12 N. Espinosa, M. Hösel, D. Angmo and F. C. Krebs, Energy Env. Sci, 2012, 5, 5117-5132.

13 V. M. Fthenakis, H. C. Kim, R. Frischknecht, M. Raugei, P. Sinha and M. Stucki, Life Cycle Inventories and Life Cycle Assessments of Photovoltaic Systems, International Energy Agency (IEA).

14 D. J. Murphy, C. A. S. Hall, M. Dale and C. Cleveland, Sustainability, 2011, 3, 1888-1907.

15 F. C. Krebs, N. Espinosa, M. Hösel, R. R. Søndergaard and M. Jørgensen, Adv. Mater., 2014, 26, 2939.

16 D. Angmo, M. Hösel and F. C. Krebs, in Organic Photovoltaics, eds. C. Brabec, U. Scherf and V. Dyakonov, Wiley-VCH Verlag GmbH \& Co. KGaA, 2014, pp. 561-586.

17 P. Sommer-Larsen, M. Jørgensen, R. R. Søndergaard, M. Hösel and F. C. Krebs, Energy Technol., 2013, 1, 15-19.

18 M. Wolf, R. Pant, K. Chomkhamsri, S. Sala and D. Pennington, European Commission (EC) - Joint Research Centre - Institute for Environment and Sustainability, International Reference Life Cycle Data System (ILCD) Handbook - Recommendations for Life Cycle Impact Assessment in the European context. EUR 24571 EN. Publications Office of the European Union, Luxembourg, 2012.

19 V. M. Fthenakis and E. A. Alsema, Prog. Photovolt. Res. Appl., 2006, 14, 275-280.

20 J. H. Schmidt and B. P. Weidema, Int. J. Life Cycle Assess., 2008, 13, 235-239.

21 The ecoinvent database v3.1. Swiss Centre for Life Cycle Inventories, Ecoinvent Centre, 2014.

22 E. Moreno Ruiz, T. Lévová, G. Bourgault and G. Wernet, Documentation of changes implemented in ecoinvent version 3.1 (2014.06.30), ecoinvent, Zurich, 2014.

23 SimaPro 8.0.4.26, PRé Consultants, Amersfoort, NL, 2015.

24 K. Treyer and C. Bauer, Int. J. Life Cycle Assess., 2013, 1-19.

25 Energinet (2015) Personal Communication (February 2015), .

26 T. Huld, R. Müller and A. Gambardella, Sol. Energy, 2012, 86, 1803-1815.

27 J. Li, L. Ma, S. Wang, W. M. Xu and F. Lu, Background paper: Chinese Renewables Status Report October 2009, REN 21- Renewable Energy Policy Network for the 21st Century, 2009.

28 J. H. Schmidt, Plastberegner.dk - LCA tool for plastics converters in Denmark - Documentation of the tool and database, 2012.

29 H. Tian, J. Gao, J. Hao, L. Lu, C. Zhu and P. Qiu, J. Hazard. Mater., 2013, 252-253, 142-154.

30 X. Chen, Y. Geng and T. Fujita, Waste Manag., 2010, 30, 716-724.

31 D. Q. Zhang, S. K. Tan and R. M. Gersberg, J. Environ. Manage., 2010, 91, 1623-1633.

32 N. J. Themelis and Z. Zhixiao, in WasteEng Conference, Beijing, 2010.

33 M. Z. Hauschild, M. Goedkoop, J. Guinée, R. Heijungs, M. Huijbregts, O. Jolliet, M. Margni, A. De Schryver, S. Humbert, A. Laurent, S. Sala and R. Pant, Int. J. Life Cycle Assess., 2013, 18, 683-697. 

perspectives. Energy and Environmental Science 8, 2537-2550. DOI: 10.1039/C5EE01763G.

34 M. Goedkoop, R. Heijungs, M. Huijbregts, A. De Schryver, J. Struijs and R. van Zelm, Life Cycle Impact Assess. Method Which Comprises Harmon. Categ. Indic. Midpoint Endpoint Level, 2009, 1.

35 A. Laurent and M. Z. Hauschild, in LCA Compendium - The Complete World of Life Cycle Assessment, Springer, Dordrecht, NL., 2015, pp. 271-300.

36 M. Hauschild, S. I. Olsen, E. Hansen and A. Schmidt, Int. J. Life Cycle Assess., 2008, 13, 547-554.

37 M. Owsianiak, A. Laurent, A. Bjørn and M. Z. Hauschild, Int. J. Life Cycle Assess., 2014, 19, 10071021.

38 A. Laurent, A. Lautier, R. K. Rosenbaum, S. I. Olsen and M. Z. Hauschild, Int. J. Life Cycle Assess., 2011, 16, 728-738.

39 N. Espinosa, A. Laurent, G. A. dos Reis Benatto, M. Hösel and F. C. Krebs, Adv. Energy Mater., 2015, Submitted.

40 N. C. McDonald and J. M. Pearce, Energy Policy, 2010, 38, 7041-7047.

41 T. Katami, A. Yasuhara, T. Okuda and T. Shibamoto, Environ. Sci. Technol., 2002, 36, 1320-1324.

42 G. J. Zheng, A. O. W. Leung, L. P. Jiao and M. H. Wong, Environ. Int., 2008, 34, 1050-1061.

43 Trellis Earth, Life Cycle Assessment (LCA) of Trellis Earth ${ }^{\circledR}$ Bioplastic Relative to Conventional Polymers, 2014.

44 A. Laurent, I. Bakas, J. Clavreul, A. Bernstad, M. Niero, E. Gentil, M. Z. Hauschild and T. H. Christensen, Waste Manag., 2014, 34, 573-588.

45 J. C. Michaud, L. Farrant, O. Jan, B. Kjla er and I. Bakas, Waste Resour. Action Programme Banbury, 2010.

46 L. Serrano-Luján, N. Espinosa, J. Abad and A. Urbina, Renew. Energy, 2015, Submitted.

47 I. T. Herrmann and M. Z. Hauschild, CIRP Ann. - Manuf. Technol., 2009, 58, 13-16.

48 COST Action MP 1307: Stable Next-Generation Photovoltaics: Unraveling degradation mechanisms of Organic Solar Cells by complementary characterization techniques (StableNextSol), 2014. 